\title{
Article \\ Community Preparation and Vulnerability Indices for Floods in Pahang State of Malaysia
}

\author{
Alias Nurul Ashikin ${ }^{1}\left(\mathbb{D}\right.$, Mohd Idris Nor Diana ${ }^{1, * \mathbb{D}}$, Chamhuri Siwar $^{1}$, Md. Mahmudul Alam ${ }^{2}(\mathbb{D}$ \\ and Muhamad Yasar ${ }^{3}$ \\ 1 Institute for Environment and Development (LESTARI), Universiti Kebangsaan Malaysia, UKM Bangi, \\ Bangi 43600, Malaysia; p83836@siswa.ukm.edu.my (A.N.A.); csiwar@ukm.edu.my (C.S.) \\ 2 School of Economics, Finance and Banking, Universiti Utara Malaysia, Sintok 06010, Malaysia; \\ mahmudul@uum.edu.my \\ 3 Department of Agricultural Engineering, Faculty of Agriculture, Universitas Syiah Kuala, \\ Banda Aceh 23111, Indonesia; yasar@unsyiah.ac.id \\ * Correspondence: nordiana@ukm.edu.my; Tel.: +60-3-89217657
}

check for updates

Citation: Nurul Ashikin, A.; Nor Diana, M.I.; Siwar, C.; Alam, M.M.; Yasar, M. Community Preparation and Vulnerability Indices for Floods in Pahang State of Malaysia. Land 2021, 10, 198. https://doi.org/ 10.3390/land10020198

Academic Editor: Marina Cabral Pinto

Received: 18 January 2021

Accepted: 3 February 2021

Published: 16 February 2021

Publisher's Note: MDPI stays neutral with regard to jurisdictional claims in published maps and institutional affiliations.

Copyright: (c) 2021 by the authors. Licensee MDPI, Basel, Switzerland. This article is an open access article distributed under the terms and conditions of the Creative Commons Attribution (CC BY) license (https:// creativecommons.org/licenses/by/ $4.0 /)$.

\begin{abstract}
The east coast of Malaysia is frequently hit by monsoon floods every year that severely impact people, particularly those living close to the river bank, which is considered to be the most vulnerable and high-risk areas. We aim to determine the most vulnerable area and understand affected residents of this community who are living in the most sensitive areas caused by flooding events in districts of Temerloh, Pekan, and Kuantan, Pahang. This study involved collecting data for vulnerability index components. A field survey and face-to-face interviews with 602 respondents were conducted 6 months after the floods by using a questionnaire evaluation based on the livelihood vulnerability index (LVI). The findings show that residents in the Temerloh district are at higher risk of flooding damage compared to those living in Pekan and Kuantan. Meanwhile, the contribution factor of LVI-Intergovernmental Panel on Climate Change (IPCC) showed that Kuantan is more exposed to the impact of climate change, followed by Temerloh and Pekan. Among all the principal components shown, food components were considered to be the most vulnerable. Meanwhile, water components were categorised as the most invulnerable. Preventive planning involves preserving human life, minimising damage to household products, preserving crops and animals, adequate supply of clean water and food, good health and ensuring financial sustainability as an indication of changing livelihoods, sustainable food-storing systems, and other protective steps to curb damage and injury caused by annual flood strikes. Information generated on LVI assessment and adaptation procedures will help policymakers reduce people's vulnerability in the face of floods and ensure proper plans are put in place in all relevant areas.
\end{abstract}

Keywords: livelihood vulnerability indices; flood; flood adaptation; preventive planning; Pahang; Malaysia

\section{Introduction}

Malaysia is now exposed to climate-change risks due to its geographical position in which susceptibility to floods is now serious [1]. Flooding, a natural phenomenon that occurs in Malaysia frequently, happens almost every year, specifically during the monsoon season. The north-eastern rainy season starts typically in November and continues till late March [2]. Pahang, one of the coastal areas of Peninsular Malaysia, is heavily affected by both northern cool weather and high-speed wind. Besides, this coastal area experiences huge amounts of rainfall throughout the early and mid-monsoon season, and specifically, rainfall during November to January causes disastrous floods in this part of the country [3]. The characteristics of the rainfall of the east-coast area as opposed to the central and southern parts of Peninsular Malaysia were such that the east-coast area received more annual precipitation with greater variability [4]. Floods in 2014 have been consider among 
the worst floods after 2007 [5]. Floods cause the nation significant losses in terms of property damage [6], loss of life, financial loss, and extensive damage to agricultural land and livestock [1]. The damage caused by floods greatly hinders Malaysian society's economic development because much time and many resources are required to recover from the disaster itself.

This study was done by using five livelihood assets in sustainable livelihood approach (SLA) framework, as in the study done by Hahn and colleagues in 2009. SLA framework was established by Chamber and Conway in 1991. This framework could be used to better understanding especially on the livelihood of poor communities [7], including flood victims as a vulnerable group. Beside that, it would explain more about the factors that affect human livelihood and could be used for future plans for sustainable development for communities affected by floods and climate change [8]. There is less study on livelihood vulnerability index on communities exposed to floods risk done in Malaysia. Most of the studies normally focus on socioeconomic impact: loss and damages.

Vulnerability has been identified as a function of exposure, sensitivity, and adaptive potential by the Intergovernmental Panel on Climate Change (IPCC) [9]. The IPCC has defined 'exposure' as the form and extent to which large environmental variations impact on society and the mechanism that drives it. These factors are mainly related to socioeconomic circumstances [10]. Vulnerability is often distinct in terms of the contexts which may generate damage caused by natural disasters directly and indirectly; these include physical and socioeconomic aspects [11]. Environmental changes somehow affect culture and nature and furthermore create problems concerning environmental protection and threats to it. According to the study, the residents living on the floodplain are greatly influenced by human exposure (potential for mortality). Certain types of infrastructure and equipment are deemed to be substantially exposed to economic harm.

Sensitivity is defined as the degree to which perturbations or climate-related stimuli impact a system. Next, the adaptive capacity of the government is defined as the ability of the state to adapt to environmental hazards, create, and/or change policies, and simultaneously increase capacity to cope with changing situations. Vulnerability is often measured through different indices including socioeconomic and biophysical indicators. This vulnerability assessment primarily identifies vulnerable individuals or groups in an area through the lens of economic and biophysical indicators.

This study uses the livelihood vulnerability index (LVI) techniques to understand the average coping capacity when natural catastrophes impact on households. More specifically, using this method, households' susceptibility to flood impacts was evaluated. LVI methods consist of five fundamental elements: physical, natural, social, financial, and human capital [8]. LVI techniques may help officials to refine and focus policies that respond to the specific needs of households and the geographic areas in which they are located. For example, using vulnerability indices/indicators, policymakers can plan mitigation and adaptation strategies $[8,12,13]$ and compare monitored conditions of vulnerability over time and in the different areas, establishing where resources need to be allocated [14,15].

However, given the complicated factors that affect communities, it is essential to devise sound and robust measures of vulnerability [16]. To comprehend the precise outcomes of floods on households in the vulnerable areas, the two popular LVI and IPCC techniques used. These two measures are the best fit for exploring both natural-disaster and climatevariability components. People's ability to adapt to urgent food, health, water and property outcomes is largely shaped by sociodemographic realities, networking, and livelihood strategies $[17,18]$. Household incomes and financial reserves constitute a vital determinant of their adaptive ability to survive the damage caused by floods.

The strategic method of the LVI and IPCC systems provides a better understanding of community vulnerability for government agencies, policymakers, NGOs, and public healthcare professionals. This research seeks to determine the vulnerability of people in Pahang who are affected by floods, specifically the Temerloh, Pekan, and Kuantan districts. The findings will assist decision makers, local authorities, and stakeholders to manage 
floods properly in the future. These areas are vulnerable ones and suffered greatly from the floods of 2014-2015. Through the subsistence index, it is possible identify the impacted subcomponents that exert a major effect on the level of vulnerability among flood-affected communities in the study area. Results of this analysis can contribute knowledge to the community by identifying the internal and external factors that can be controlled when danger strikes. It can also guide government agencies/departments to find those areas most affected socially, economically, and environmentally. In this way, it can help the government to formulate effective and targeted strategies according to the type of vulnerability and area concerned, and in turn, it can ensure that flood victims have sustainable livelihoods throughout the whole of Pahang, not just the specific study areas.

\section{Materials and Methods}

\subsection{Study Area}

Pahang is an extremely important state in Peninsular Malaysia. It is located in the eastern coastal region of Malaysia, and it was one of the worst affected areas during the floods of 2014. The most significant catchment area of Pahang state is the Pahang River basin where annual flood events take place every year. This river is situated in the central part of the Malaysian peninsula, between the Titiwangsa range in the west and the Timur range in the east. The river particularly affects the lives and economic circumstances of inhabitants in the districts of Temerloh, Pekan, and Kuantan almost every year (Figure 1). For example, this river is the place on which 1.9 million people depend for their livelihoods [19]. The annual precipitation in the river basin ranges from 1700 to $2800 \mathrm{~mm}$. The highest intensity of the rainfall can reach 200,450 $\mathrm{mm}$ per day and $60 \mathrm{~mm}$ in an hour, which simply increases the quantity of water spectacularly and creates dangerous overflows $[20,21]$. Most people live in the lower areas, and the region is characterised by a weak irrigation system [22].

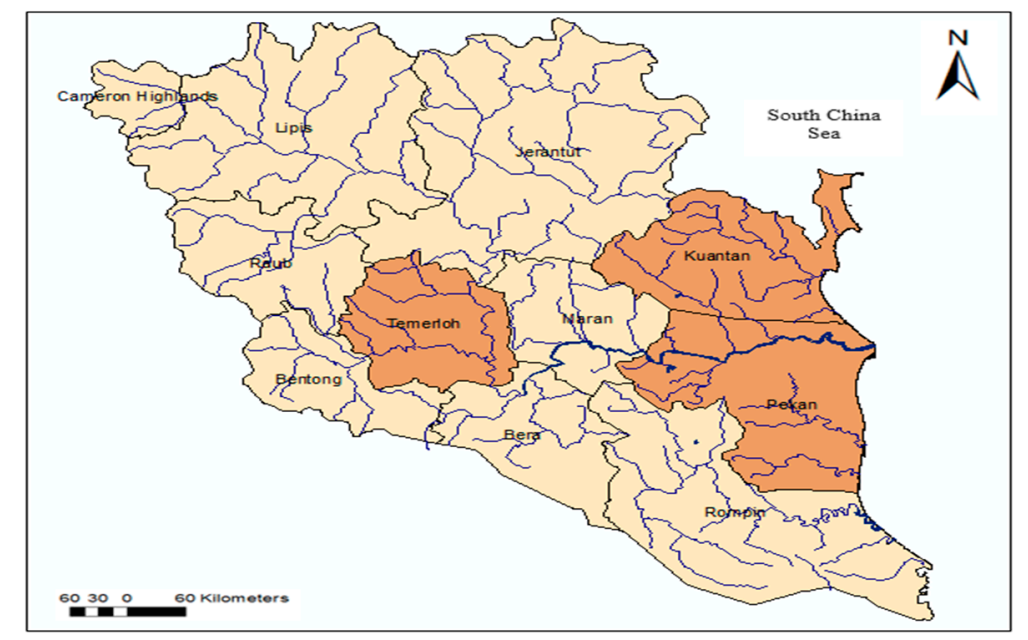

Figure 1. Map showing the districts of Temerloh, Pekan, and Kuantan.

\subsection{Household Surveys}

The primary data were collected in 2015 from the people live in the Temerloh, Pekan, and Kuantan districts. Meanwhile the secondary data were collected from reports published by government agencies. In total, 57 key variables were derived from the 10 principal components using LVI measurement presented in Table 1. Face-to-face interviews were conducted with 602 people in all three districts concerning the flood events of 2014. The focus group comprised residents who were most likely to be inundated in the area and from a variety of socioeconomic groups. Analysis of the livelihood vulnerability index (LVI) was done and based on the five essential components of the sustainable livelihood framework, which later was expanded to 10 components as noted in other studies [23-32]. Seven new 
subcomponents have been introduced for LVI analysis to evaluate the vulnerability of an affected community.

Table 1. Livelihood vulnerability index (LVI) of principal components and subcomponents.

\begin{tabular}{|c|c|c|c|c|}
\hline Main Components & Subcomponents & Unit & Description & Sources \\
\hline \multirow[t]{8}{*}{ Social demographic } & Dependency ratio & Ratio & $\begin{array}{l}\text { The number of people } \\
\text { under } 15 \text { and over } 65 \text { years } \\
\text { of age to people between } \\
19 \text { and } 64 \text { years of age. }\end{array}$ & [23-32] \\
\hline & $\begin{array}{l}\text { Percentage of } \\
\text { female-headed } \\
\text { households }\end{array}$ & $\%$ & $\begin{array}{l}\text { The primary adult is a } \\
\text { woman whose male head is } \\
\text { away from home, for } \\
\text { example more than six } \\
\text { months a year. }\end{array}$ & [23-30] \\
\hline & $\begin{array}{l}\text { The average age of } \\
\text { female-headed } \\
\text { households }\end{array}$ & Count & $\begin{array}{l}\text { Average age of female } \\
\text { adult at the head of } \\
\text { household. }\end{array}$ & {$[25,26,28,29]$} \\
\hline & $\begin{array}{l}\text { Percentage of families } \\
\text { where the head of the } \\
\text { household has not } \\
\text { attended school }\end{array}$ & $\%$ & $\begin{array}{l}\text { The head of the family unit } \\
\text { reported that they never } \\
\text { attended formal education. }\end{array}$ & [23-32] \\
\hline & $\begin{array}{l}\text { The average number of } \\
\text { people in households }\end{array}$ & Count & $\begin{array}{l}\text { Average of household } \\
\text { members for each family. }\end{array}$ & {$[25,26,32]$} \\
\hline & $\begin{array}{l}\text { Percentage of homes } \\
\text { with orphans }\end{array}$ & $\%$ & $\begin{array}{l}\text { Houses with a minimum of } \\
\text { one orphan in their family. } \\
\text { The age of the orphan must } \\
\text { be less than } 18 \text {, and one or } \\
\text { both of his/her parents } \\
\text { must be dead }\end{array}$ & {$[23,25,28,29]$} \\
\hline & $\begin{array}{l}\text { Percentage of } \\
\text { households of which a } \\
\text { member has no formal } \\
\text { or informal skills }\end{array}$ & $\%$ & $\begin{array}{l}\text { Percentage of household } \\
\text { members without any } \\
\text { formal or informal skill. } \\
\text { Formal skill such as } \\
\text { operating engine vehicle } \\
\text { which require license. } \\
\text { Informal skill such as } \\
\text { swimming, might be } \\
\text { taught by family member }\end{array}$ & Adapted from [24] \\
\hline & $\begin{array}{l}\text { Percentage of poor } \\
\text { households (income } \\
\text { below RM490) }\end{array}$ & $\%$ & $\begin{array}{l}\text { Percentage of households } \\
\text { that are counted in the } \\
\text { poor and hardcore poor } \\
\text { categories according to } \\
\text { poverty-line income (PLI) } \\
\text { in Malaysia. }\end{array}$ & {$[25,26]$} \\
\hline \multirow[t]{4}{*}{ Livelihood strategy } & $\begin{array}{l}\text { Where at least one } \\
\text { member of the family } \\
\text { works in another city }\end{array}$ & $\%$ & $\begin{array}{l}\text { Households where at least } \\
\text { one family member's } \\
\text { primary job is outside the } \\
\text { local community. }\end{array}$ & {$[23-26,28,29]$} \\
\hline & $\begin{array}{l}\text { Families depend } \\
\text { primarily on } \\
\text { agriculture as their } \\
\text { primary source of } \\
\text { income }\end{array}$ & $\%$ & $\begin{array}{l}\text { Agriculture is the principal } \\
\text { source of a household's } \\
\text { income. }\end{array}$ & {$[23-26,29,32]$} \\
\hline & $\begin{array}{l}\text { Diversification of } \\
\text { average agriculture } \\
\text { industry livelihoods }\end{array}$ & 1/\# livelihood & $\begin{array}{l}\text { The inverse of (number of } \\
\text { farm livelihood activities }+ \\
\text { 1) recorded by a household. } \\
\text { The formula is written } \\
\text { below: }\end{array}$ & {$[23-26,28-32]$} \\
\hline & & & $\frac{1}{\text { number of agricultural livelihoods }+1}$ & \\
\hline
\end{tabular}


Table 1. Cont.

\begin{tabular}{|c|c|c|c|c|}
\hline Main Components & Subcomponents & Unit & Description & Sources \\
\hline & $\begin{array}{l}\text { Agricultural } \\
\text { production proportion } \\
\text { to total income }\end{array}$ & Ratio & $\begin{array}{l}\text { Ratio total value of farm } \\
\text { earnings from agriculture } \\
\text { (e.g., crops and livestock) } \\
\text { to total income. }\end{array}$ & Adapted from [30] \\
\hline & $\begin{array}{l}\text { Percentage of the } \\
\text { household's income } \\
\text { with contribution from } \\
\text { agricultural activity }\end{array}$ & $\%$ & $\begin{array}{l}\text { Percentage of household's } \\
\text { income from agricultural } \\
\text { work either completely or } \\
\text { partially. }\end{array}$ & Author's \\
\hline & $\begin{array}{l}\text { Percentage of } \\
\text { households losing a job } \\
\text { during flood season }\end{array}$ & $\%$ & $\begin{array}{l}\text { Percentage of households } \\
\text { in which family member } \\
\text { lost his/her job due to the } \\
\text { floods. }\end{array}$ & {$[25,26]$} \\
\hline & $\begin{array}{l}\text { Households finding } \\
\text { new natural resources } \\
\text { during times of flood }\end{array}$ & $\%$ & $\begin{array}{l}\text { Percentage of households } \\
\text { that use natural resources } \\
\text { to survive during the } \\
\text { floods. }\end{array}$ & {$[25,26]$} \\
\hline & $\begin{array}{l}\text { Percentage of } \\
\text { households that catch } \\
\text { fish during flood } \\
\text { seasons }\end{array}$ & $\%$ & $\begin{array}{l}\text { Percentage of households } \\
\text { resorting to fishing during } \\
\text { floods. }\end{array}$ & {$[25,26]$} \\
\hline \multirow[t]{6}{*}{ Health } & $\begin{array}{l}\text { Households where at } \\
\text { least one member has a } \\
\text { health problem }\end{array}$ & $\%$ & $\begin{array}{l}\text { Families who have at least } \\
\text { one person in their family } \\
\text { with a chronic illness. The } \\
\text { respondents reported the } \\
\text { illness themselves. }\end{array}$ & [23-30] \\
\hline & $\begin{array}{l}\text { Percentage of } \\
\text { households not able to } \\
\text { store medicine during } \\
\text { floods }\end{array}$ & $\%$ & $\begin{array}{l}\text { Percentage of households } \\
\text { not storing medicine for } \\
\text { personal use during floods. }\end{array}$ & Author's \\
\hline & $\begin{array}{l}\text { Percentage of } \\
\text { households having } \\
\text { access to a healthcare } \\
\text { facility }\end{array}$ & $\%$ & $\begin{array}{l}\text { A majority of identified } \\
\text { households were unable to } \\
\text { access the nearest } \\
\text { healthcare centre. }\end{array}$ & Adapted from $[24,32]$ \\
\hline & $\begin{array}{l}\text { Average time the } \\
\text { nearby healthcare } \\
\text { facility (with at least } \\
\text { one qualified doctor) }\end{array}$ & $\%$ & $\begin{array}{l}\text { Average time taken for } \\
\text { households to get to a } \\
\text { nearby healthcare facility. }\end{array}$ & {$[23,25-32]$} \\
\hline & $\begin{array}{l}\text { For the last two weeks, } \\
\text { a percentage of } \\
\text { households with a } \\
\text { family member who } \\
\text { had to miss work or } \\
\text { school because of flood } \\
\text { disease. }\end{array}$ & $\%$ & $\begin{array}{l}\text { Due to illness at least one } \\
\text { person in their family } \\
\text { misses school or work in } \\
\text { the last two weeks. }\end{array}$ & {$[23,25-32]$} \\
\hline & $\begin{array}{l}\text { The proportion of } \\
\text { households with family } \\
\text { members contracting a } \\
\text { disease due to floods }\end{array}$ & Ratio & $\begin{array}{l}\text { A percentage of } \\
\text { households indicated that } \\
\text { at least one member of the } \\
\text { family was sick due to } \\
\text { flooding. } \\
\text { Households that lent } \\
\text { money in recent months (if } \\
\text { a house borrowed money } \\
\text { but did not offer money, } \\
\text { the ratio would be } 2: 1 \text {; if } \\
\text { they lent money but did } \\
\text { not borrow anything, the } \\
\text { ratio would be } 1: 2 \text { or } 0.5 \text {. }\end{array}$ & [24-29] \\
\hline
\end{tabular}


Table 1. Cont.

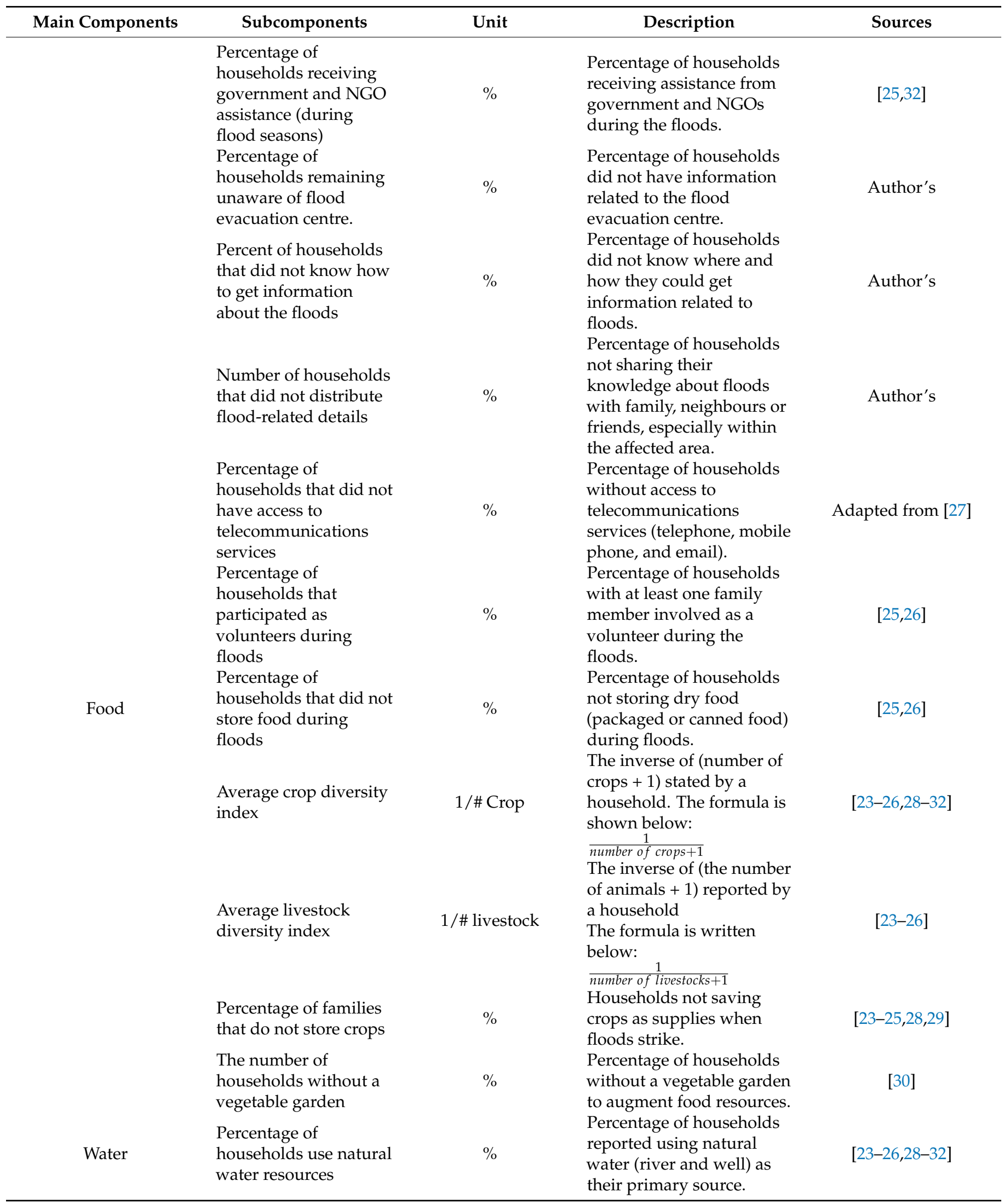


Table 1. Cont.

\begin{tabular}{|c|c|c|c|c|}
\hline Main Components & Subcomponents & Unit & Description & Sources \\
\hline & $\begin{array}{l}\text { Percentage of } \\
\text { households that do not } \\
\text { have daily sources of } \\
\text { water }\end{array}$ & $\%$ & $\begin{array}{l}\text { Percentage of household } \\
\text { reporting that water is not } \\
\text { consistently available at } \\
\text { their primary water source } \\
\text { for daily usage. }\end{array}$ & {$[23-26,28,29]$} \\
\hline & $\begin{array}{l}\text { Percentage of } \\
\text { households have to go } \\
\text { further to get water. }\end{array}$ & $\%$ & $\begin{array}{l}\text { Percentage of households } \\
\text { reporting they need to get } \\
\text { water from somewhere } \\
\text { else. }\end{array}$ & [24] \\
\hline & $\begin{array}{l}\text { Percentage of } \\
\text { households storing } \\
\text { water }\end{array}$ & $\%$ & $\begin{array}{l}\text { Percentage of families that } \\
\text { store water for daily usage. }\end{array}$ & [24] \\
\hline & $\begin{array}{l}\text { Average distance to } \\
\text { water resources }\end{array}$ & Minutes & $\begin{array}{l}\text { The average time taken by } \\
\text { each household to travel to } \\
\text { their primary water source. }\end{array}$ & {$[23,25-32]$} \\
\hline & $\begin{array}{l}\text { The opposite of the } \\
\text { total amount of litres of } \\
\text { water per household } \\
\text { deposited }\end{array}$ & 1/\# Litre & $\begin{array}{l}\text { The opposite of (average } \\
\text { number of litres of water } \\
\text { store by each house }+1 \text { ) } \\
\text { The formula as below: } \\
\frac{1}{\text { litres }+1}\end{array}$ & {$[23,25,26,28,29]$} \\
\hline House & $\begin{array}{l}\text { Percentage of } \\
\text { households whose } \\
\text { house does not have a } \\
\text { solid structure } \\
\text { (wood/semi-wood) }\end{array}$ & $\%$ & $\begin{array}{l}\text { Percentage of households } \\
\text { with homes built from } \\
\text { nonsolid materials (wood a } \\
\text { semi-wood) and prone to } \\
\text { damage by floods. }\end{array}$ & {$[25,26]$} \\
\hline & $\begin{array}{l}\text { The number of houses } \\
\text { not built above the } \\
\text { ground to deter } \\
\text { flooding }\end{array}$ & $\%$ & $\begin{array}{l}\text { Percentage of families } \\
\text { which did not build homes } \\
\text { above ground level to } \\
\text { prevent floods. }\end{array}$ & {$[25,26]$} \\
\hline \multirow{8}{*}{ Finance and income } & $\begin{array}{l}\text { Percentage of } \\
\text { flood-affected } \\
\text { households }\end{array}$ & $\%$ & $\begin{array}{l}\text { Percentage of families } \\
\text { affected by floods (more } \\
30 \% \text { damage). Respondent } \\
\text { subjectively defined level } \\
\text { of damage. }\end{array}$ & {$[25,26]$} \\
\hline & $\begin{array}{l}\text { Families who are not } \\
\text { owners of the land area } \\
\text { remain on (landless) }\end{array}$ & $\%$ & $\begin{array}{l}\text { Percentage of households } \\
\text { that do not own the land } \\
\text { they live on. }\end{array}$ & [24-26] \\
\hline & $\begin{array}{l}\text { Percentage of } \\
\text { households }(0.1-0.5 \mathrm{ha}) \\
\text { with a limited land area }\end{array}$ & $\%$ & $\begin{array}{l}\text { Percentage of households } \\
\text { owning only a small area } \\
\text { of land. }\end{array}$ & {$[25,26]$} \\
\hline & $\begin{array}{l}\text { Percentage of the } \\
\text { household without } \\
\text { fertile land }\end{array}$ & $\%$ & $\begin{array}{l}\text { Percentage of families that } \\
\text { did not possess a good area } \\
\text { for agricultural activity. }\end{array}$ & Adapted from [24] \\
\hline & $\begin{array}{l}\text { Households who are } \\
\text { affected in their income } \\
\text { due to floods }\end{array}$ & $\%$ & $\begin{array}{l}\text { Percentage of households } \\
\text { with affected incomes due } \\
\text { to floods. }\end{array}$ & {$[25,26]$} \\
\hline & $\begin{array}{l}\text { Percentage of } \\
\text { households that fall } \\
\text { under B } 40 \text { category }\end{array}$ & $\%$ & $\begin{array}{l}\text { Percentage of households } \\
\text { with monthly income of } \\
\text { RM3860 and less. }\end{array}$ & Author's \\
\hline & $\begin{array}{l}\text { Percentage of } \\
\text { households have the } \\
\text { burden of loan }\end{array}$ & $\%$ & $\begin{array}{l}\text { Percentage of households } \\
\text { taking out a loan from } \\
\text { individual or institution. }\end{array}$ & [24-26] \\
\hline & $\begin{array}{l}\text { No money was saved } \\
\text { by a number of } \\
\text { households }\end{array}$ & $\%$ & $\begin{array}{l}\text { Proportion of households } \\
\text { that did not save money } \\
\text { for other expenses. }\end{array}$ & Author's \\
\hline
\end{tabular}


Table 1. Cont.

\begin{tabular}{|c|c|c|c|c|}
\hline Main Components & Subcomponents & Unit & Description & Sources \\
\hline \multirow{6}{*}{$\begin{array}{c}\text { Natural Disaster and } \\
\text { Climate variability }\end{array}$} & $\begin{array}{l}\text { The total number of } \\
\text { floods (range: } 0-7 \text { ) over } \\
\text { the past seven years }\end{array}$ & Count & $\begin{array}{l}\text { Comprehensive number of } \\
\text { flooding cases recorded by } \\
\text { households in the past } \\
\text { seven years. }\end{array}$ & {$[23-26,28-32]$} \\
\hline & $\begin{array}{l}\text { Percentage of } \\
\text { households that were } \\
\text { not provided early } \\
\text { flood warnings }\end{array}$ & $\%$ & $\begin{array}{l}\text { Early-warning information } \\
\text { on flooding was not } \\
\text { obtained by a percentage of } \\
\text { households. }\end{array}$ & {$[23-26,28-32]$} \\
\hline & $\begin{array}{l}\text { Percentage of } \\
\text { households with } \\
\text { damage from flooding } \\
\text { to property }\end{array}$ & $\%$ & $\begin{array}{l}\text { Percentage of households } \\
\text { suffering damage/loss of } \\
\text { physical assets (agriculture } \\
\text { and building structures) } \\
\text { due to floods. }\end{array}$ & {$[25,26,32]$} \\
\hline & $\begin{array}{l}\text { Percentage of family } \\
\text { members experiencing } \\
\text { catastrophe accidents } \\
\text { or deaths from floods } \\
\text { in the last seven years }\end{array}$ & $\%$ & $\begin{array}{l}\text { Percentage of households } \\
\text { who registered injury or } \\
\text { death to at least one family } \\
\text { member in the last seven } \\
\text { years due to extreme } \\
\text { floods. }\end{array}$ & {$[23-26,28-32]$} \\
\hline & $\begin{array}{l}\text { Mean standard } \\
\text { deviation monthly } \\
\text { rainfall }\end{array}$ & Count & $\begin{array}{l}\text { Average standard } \\
\text { deviation value of monthly } \\
\text { precipitation in } 2014 \text {. }\end{array}$ & Adapted from [30-32] \\
\hline & $\begin{array}{l}\text { Mean standard } \\
\text { deviation monsoon } \\
\text { rainfall }\end{array}$ & Count & $\begin{array}{l}\text { Average standard } \\
\text { deviation value of } 2014 \\
\text { monsoon precipitation. }\end{array}$ & Adapted from $[30,32]$ \\
\hline
\end{tabular}

The 10 main components evaluated in this study are social demographic profile, livelihood strategy, social network, food, water, health, financial, land, house, and naturaldisaster and climate variability. The main components of social demographic profile, livelihood strategy, and social network are to evaluate the adaptive capacity of the population. Meanwhile, food, water, health, financial, land and house are to measure the sensitivity of population towards floods. Lastly, the component of natural-disaster and climate variability is used to measure exposure of flood risk on the population. All principal components and subcomponents have been represented in Table 1.

\subsection{Data Analysis}

\subsubsection{Vulnerability Index for Livelihood (LVI)}

This study implements a compound index analysis approach to evaluate the livelihood vulnerability index (LVI). It includes air, house, social demographic profile, finance, and natural disaster, livelihood strategy, social network, food, land, and climate variability. Table 1 below summarises the principle components and subcomponents. The livelihood vulnerability index (LVI) measurement uses Equation (1), which is written below:

$$
\text { index }_{S_{d}}=\frac{S_{d}-S_{\min }}{S_{\max }-S_{\min }}
$$

referring to Equation (1), $S_{d}$ (district d), $S_{\min }$ (minimum), and $S_{\text {max }}$ (maximum) value, respectively. Then, we calculated the average for the standardisation value of each subcomponent employing Equation (2) to calculate every key component.

$$
M_{d}=\frac{\sum_{i=1}^{n} \text { index }_{S_{d_{i}}}}{n}
$$

Meanwhile, Equation (2) Md used to calculate of 10 significant major components for district $d$ [social demographic profile (SDP), livelihood strategy (LS), financial (Fi), health 
$(\mathrm{H})$, social network $(\mathrm{SN})$, food $(\mathrm{F})$, water $(\mathrm{A})$, land $(\mathrm{L})$, and natural-disaster and climate variability $(\mathrm{NDCV})] . S_{d_{i}}$ is the main components, indexed by $i$, that make up each major element and $n$ is the number of subcomponents. The values of all 10 vital elements for a community were summed by using calculation (3) to obtain the LVI for each area:

$$
L V I_{d}=\frac{\sum_{i=1}^{n} W_{M_{i}} M_{d_{i}}}{\sum_{i=1}^{n} W_{M_{i}}}
$$

$L V I_{d}$ refers to LVI for area $d$ which had equally weighted 10 major components. The weights for each significant element and the number of subcomponents were calculated by $w_{M_{i}}$. It served to certify that all subcomponents contribute proportionately to the overall LVI. Evaluation scale for the livelihood vulnerability index (LVI) ranges from 0 (most invulnerable) to 1 (most vulnerable). The LVI scale was divided into four levels starting from most invulnerable $(0.000-0.250)$, invulnerable $(0.251-0.500)$, vulnerable $(0.510-0.750)$ and most vulnerable (0.751-1.000). These are reported in Table 2 below.

Table 2. Livelihood vulnerability index (LVI) vulnerability.

\begin{tabular}{cc}
\hline Scale & Ranges \\
\hline Most Invulnerable & $0.000-0.250$ \\
Invulnerable & $0.251-0.500$ \\
Vulnerable & $0.501-0.750$ \\
Most Vulnerable & $0.751-1.000$ \\
\hline
\end{tabular}

\subsubsection{LVI according to the IPCC approach}

The IPCC approach incorporates three dimensions with 10 major components, for instance exposure (Exp), adaptive capacity (AdaCap), and sensitivity (Sen), that are a part of the vulnerability analysis. These three dimensions were combined and calculated using equation below (4):

$$
L V I-I P C C_{d}=\left(\operatorname{Exp}_{d}-\text { AdaCap }_{d}\right) * \operatorname{Sen}_{d}
$$

where, LVI-IPCC $C_{d}$ determines the LVI for community $d$ using the IPCC vulnerability context. The minimum value for LVI and IPCC is -1 (slightly vulnerable) up to 1 (extremely vulnerable). The IPCC approach incorporates three dimensions with 10 major components, for instance, exposure (Exp), adaptive capacity (AdaCap), and sensitivity (Sen), that are a part of the vulnerability analysis.

\subsection{Limitation}

There were difficulties in determining the precise and suitable subcomponent's variable in order to measure LVI at three districts in Pahang. Normally, the subcomponents would be determined through explanatory or literature review. However, is it enough to represent the real situation of LVI in that area? Thus, the process to determine subcomponents became one of the greatest limitations for LVI study.

\section{Findings}

Table 3 documents the social demographic profiles of respondents in Temerloh, Pekan, and Kuantan. Most of the respondents from Pekan and Temerloh live in rural areas, while most people in Kuantan reside in urban areas. More than $50 \%$ of participants in all three districts are male, so they comprise the majority gender. Although this survey was intended for each household's male adult, their wives could answer the survey questions on behalf of their husbands if they were not at home. Most of the respondents in Pekan and Temerloh are between 41 to 65 years old, while in Kuantan the majority of respondents are between 19 to 40 years of age. This explained why the average age of respondents in Kuantan (43 years old) is much younger than in Temerloh (51 years old) and Pekan (50 years old). 
Table 3. Respondents profiling. Source: Author analysis, 2019.

\begin{tabular}{|c|c|c|c|c|c|c|c|}
\hline Item & $\begin{array}{l}\text { Temerloh }(\%) \\
(\mathrm{n}=202)\end{array}$ & $\begin{array}{c}\text { Pekan } \\
(\%) \\
(n=200)\end{array}$ & $\begin{array}{c}\text { Kuantan } \\
(\%) \\
(n=200)\end{array}$ & Item & $\begin{array}{l}\text { Temerloh }(\%) \\
(\mathrm{n}=202)\end{array}$ & $\begin{array}{c}\text { Pekan } \\
(\%) \\
(n=200)\end{array}$ & $\begin{array}{c}\text { Kuantan } \\
(\%) \\
(n=200)\end{array}$ \\
\hline Strata & & & & Gender & & & \\
\hline Urban & 36.6 & 25 & 72.5 & Male & 56.4 & 83.5 & 51.5 \\
\hline Rural & 63.4 & 75 & 27.5 & Female & 43.6 & 16.5 & 48.5 \\
\hline Age & & & & Marital Status & & & \\
\hline $19-40$ & 21.8 & 19.5 & 49.5 & Single & 9.4 & 2.5 & 3.5 \\
\hline$>65$ & 19.3 & 9 & 6.5 & Married & 73.3 & 78 & 90 \\
\hline Age average & 51.2 & 50.2 & 42.6 & & & & \\
\hline Education Status & & & & Occupational category & & & \\
\hline Degree & 4.5 & 2.0 & 11.5 & Government & 9.4 & 12 & 22 \\
\hline Certificate & 0.5 & - & 1 & Private sector & 9.4 & 22.5 & 33.5 \\
\hline STPM/Diploma & 5.4 & 3.0 & 9.5 & Self-employed & 55 & 47 & 32 \\
\hline $\begin{array}{c}\text { SPM } \\
\text { SPD }\end{array}$ & 39.1 & 43.0 & 40.5 & Housewife & 1 & 5.5 & 1 \\
\hline SRP/PMR & 18.8 & 22.0 & 16.5 & Unemployed & 9.9 & 3 & 3 \\
\hline Primary school & 30.7 & 27.0 & $\begin{array}{c}16 \\
5\end{array}$ & Others & 15.3 & 10 & 8.5 \\
\hline
\end{tabular}


The majority of respondents are married. However, the number of widows and widowers is much higher in Temerloh and Pekan than Kuantan, and this is possibly due to more older respondents in both districts who have separated or lost their spouse. By contrast, the respondents who are single represent the smallest percentage. The majority of respondents in the three districts have Sijil Pelajaran Malaysia (SPM) as their highest level of education. A smaller number people completed their tertiary education in Temerloh $(10.5 \%)$ and Pekan (5\%) compared to those in Kuantan $(22 \%)$. It confirms that respondents in Kuantan were more likely to pursue tertiary education due to better circumstances and education facilities. In addition, $5 \%$ and less of the respondents did not go to school for any sort of formal training. In terms of occupation, more than $40 \%$ of participants in Temerloh and Pekan are self-employed. In the meantime, the majority of respondents in Kuantan work in the private sector or are self-employed. Only a small percentage of respondents work for the government: Temerloh (9.4\%), Pekan (12\%), and Kuantan (22\%). The remaining respondents were either housewives, unemployed, or other (retirees).

According to Table 3, the highest value of livelihood vulnerability index (LVI) is indicated by Temerloh district (0.374), followed by Pekan (0.359), and then Kuantan (0.344). Values of LVI for each district depended on the value of 10 major components. The level of vulnerability in terms of the social demographic profile was the highest in Temerloh (0.310), followed by Kuantan (0.292), and Pekan (0.289). Two subcomponents reported the highest vulnerability level, these being the average age of female adults in households and those members who did not have any formal or informal skills. Index value for the average number of family members and households with incomes below RM490 was not considered to mean vulnerability. Subcomponents of independent ratio, households' adult females, heads of households without education, and households with orphans have the least vulnerability index value under the social demographic profile component.

Temerloh and Pekan districts have shown the same highest vulnerability index value for a major component of livelihood strategy (0.217); meanwhile, Pekan reports a lower index value (0.173). Only one subcomponent indicated the most vulnerability, which was average agriculture livelihood diversification. The highest index value was recorded in Kuantan (0.956), followed by Temerloh (0.874) and Pekan (0.785). Most respondents in Temerloh and Pekan worked in agriculture for their livelihoods compared to respondents in Kuantan. Meanwhile, seven out of eight subcomponents were considered to be the most invulnerable categories, i.e., family member working in a different community; solely dependent on income from agriculture; ratio of agricultural income to total income; contribution of agricultural work to household's income; job lost due to floods; and finding other natural resources and resorting to fishing during floods.

Pekan of all three districts has the highest index value for a major component of health (0.228), followed by Temerloh (0.215) and Kuantan (0.197). Most of the subcomponents under health are categorised as either invulnerable or most invulnerable. Only two subcomponents reported as vulnerable value, where people do not have access to the nearest healthcare facility in Pekan (0.555), while those who do not store medicine during floods in Kuantan report a value of 0.540 . However, these two same two subcomponents documented lower index values for the other two districts. Not having access to the nearest healthcare facility in Temerloh was 0.406 , while for Kuantan it was 0.075. Meanwhile the index values for households that did not store medicines during floods were 0.208 for Temerloh and 0.370 for Pekan.

The summarize indexes (Table 4) shows that the social network component was one component of the LVI. Here the highest index value was indicated by Pekan (0.511), followed by Temerloh (0.473) and Kuantan (0.438). There are four subcomponents categorised as being the most vulnerable. Initially, two out of seven subcomponents were classified as being on the most vulnerable in Temerloh and Pekan districts; the average ratio of borrowing and lending money, and assistance received by households. Meanwhile another two most vulnerable subcomponents classified were for Pekan: households not sharing information and in Kuantan for households not volunteering during flood. The index 
values for average ratio of borrowing and lending money were as follows: Temerloh (0.933), Pekan (1), and Kuantan (0.300). Values for the subcomponent of households receiving assistance were as follows: Temerloh (0.960), Pekan (0.890), and Kuantan (0.705). Index value for sharing flood-related information for Temerloh was 0.530, while for Pekan it was 0.795 , and for Kuantan it was 0.580 . However, only the subcomponent volunteering had the highest index value in Kuantan (0.860), followed by Temerloh (0.653) and Pekan (0.660). Three out of seven components have an index value categorised as most invulnerable. These were households not having access to telecommunications, not having information about flood evacuation centre, and not knowing how to get that information.

Table 4. Summarised indexed subcomponents, main components, and total LVI for the districts of Temerloh, Pekan and Kuantan.

\begin{tabular}{cccc}
\hline Major Element & \multicolumn{3}{c}{ Major Element Index } \\
\cline { 2 - 4 } & $\mathbf{T}$ & $\mathbf{P}$ & $\mathbf{K}$ \\
\hline Social demographic profile & 0.310 & 0.289 & 0.292 \\
Livelihood strategy & 0.217 & 0.217 & 0.173 \\
Health & 0.215 & 0.228 & 0.197 \\
Social network & 0.473 & 0.511 & 0.438 \\
Food & 0.864 & 0.834 & 0.921 \\
Water & 0.110 & 0.082 & 0.069 \\
House & 0.728 & 0.578 & 0.588 \\
Land & 0.600 & 0.455 & 0.621 \\
Finance & 0.503 & 0.525 & 0.373 \\
variability & 0.297 & 0.297 & 0.292 \\
Natural disasters and climate & & & $\mathbf{0 . 3 4 7}$ \\
\hline Livelihood vulnerability index (LVI) & $\mathbf{0 . 3 8 4}$ & $\mathbf{0 . 3 6 4}$ &
\end{tabular}

Kuantan had the highest vulnerability index for food component (0.921), followed by Temerloh (0.864) and Pekan (0.834). Four out of five food subcomponents have been categorised as part of the most vulnerable index value. These are average crop diversity index, average livestock diversity index, crop storage, and household vegetable garden. All these four subcomponents have the highest index value in Temerloh, followed by Kuantan and Pekan. Only the subcomponent of food storage during a flood was in the vulnerable category with the highest index value for Kuantan (0.700), followed by Pekan (0.540) and then Temerloh (0.470). The index for water component revealed the highest vulnerability index value in Temerloh (0.110), followed by Pekan (0.082) and Kuantan (0.069). Five out of six subcomponents that were considered as part of the most invulnerable classification were utilising natural water resources, consistent water supply, fetching water from another location, storing water, and water stored per household. Only the subcomponent of average distance to water sources was classified as invulnerable category. Almost all of the subcomponents had a low vulnerability index value which amounted to 0 . The study also indicates that most subcomponent of water had the lowest vulnerability index compared to another major component of the livelihood vulnerability index (LVI).

Temerloh has the highest vulnerability index value for house component (0.728), followed by Kuantan (0.588) and Pekan (0.578). Subcomponent of homes that were not built above the ground had the highest vulnerability index. They could be categorised as most vulnerable in Kuantan (0.965) and Temerloh (0.827). However, the same subcomponent was classified as vulnerable in Pekan (0.730). Houses in Temerloh (0.812) were more affected by a flood, and they were deemed to be the most vulnerable compared to Pekan (0.445) and Kuantan (0.550). Meanwhile, houses not built build with solid concrete recorded the lowest vulnerability index, in the following order for the three districts: Pekan (0.560), Temerloh (0.545), and Kuantan (0.250). The component of land had the highest index value in Kuantan (0.544), followed by Temerloh (0.507) and Pekan (0.401). The subcomponent of households without fertile land classified as the most vulnerable between three other subcomponents 
Kuantan (1), Temerloh (0.955), and Pekan (0.845). Kuantan is most vulnerable for the subcomponent of household with limited land area (0.865) compared to Temerloh (0.702) and Pekan (0.545), which are categorised as vulnerable. Meanwhile, the subcomponent of households without land ownership gave the lowest vulnerability index value and was considered as invulnerable in Temerloh and Kuantan, however it classified as most invulnerable in Pekan.

The highest vulnerability index value for a component of finance was evident in Pekan (0.525), followed by Temerloh (0.503) and Kuantan (0.373). The subcomponent of households under B40 was categorised as the most vulnerable in Temerloh (0.965), followed by Pekan (0.915) and Kuantan (0.855). Another two subcomponents had index value classified as most invulnerable. These were household's income affected by floods and households having to pay off a loan. The subcomponent of household not saving money was classified as the most vulnerable in Pekan. However, the same subcomponent was categorised as vulnerable in Temerloh and invulnerable in Kuantan (Table 5).

Table 5. Ranking of the subcomponents of the livelihood hulnerability index based on the three regions in Pahang, Malaysia.

\begin{tabular}{cccc}
\hline \multirow{2}{*}{ Major Component } & \multicolumn{3}{c}{ Major Component Index } \\
\cline { 2 - 4 } & $\mathbf{T}$ & $\mathbf{P}$ & $\mathbf{K}$ \\
\hline Social demographic profile & $0.310^{6}$ & $0.289^{7}$ & $0.292^{6}$ \\
Livelihood strategy & $0.217^{8}$ & $0.217^{9}$ & $0.173^{9}$ \\
Health & $0.215^{9}$ & $0.228^{8}$ & $0.197^{8}$ \\
Social network & $0.473^{5}$ & $0.511^{4}$ & $0.438^{4}$ \\
Food & $0.864^{1}$ & $0.834^{1}$ & $0.921^{1}$ \\
Water & $0.110^{10}$ & $0.082^{10}$ & $0.069^{10}$ \\
House & $0.728^{2}$ & $0.578^{2}$ & $0.588^{3}$ \\
Land & $0.600^{3}$ & $0.455^{5}$ & $0.621^{2}$ \\
Finance & $0.503^{4}$ & $0.525^{3}$ & $0.373^{5}$ \\
variability & $0.297^{7}$ & $0.297^{6}$ & $0.292^{7}$ \\
Natural disasters and climate & & $\mathbf{0 . 3 6 4}$ & $\mathbf{0 . 3 4 7}$ \\
\hline Livelihood vulnerability index (LVI) & $\mathbf{0 . 3 8 4}$ & &
\end{tabular}

Source: Author analysis, 2019.

Natural-disasters and climate variability constitute the last component of the livelihood vulnerability index (LVI). The index value for this component is virtually the same for all three districts, i.e., Temerloh (0.297), Pekan (0.297), and Kuantan (0.292). Only the subcomponent of average number of floods in the last 7 years showed the highest vulnerability index value in all areas. This refers to the number of flood events reported in these three districts going back 7 years: Pekan (0.916), Temerloh (0.912), and then Kuantan (0.896). Temerloh had the highest index value for the subcomponent of households not receiving an early warning about floods (0.312) and loss of physical assets (0.396) due to flood damage, when compared to Pekan and Kuantan. Meanwhile, Pekan (0.318) had the highest index value for average monsoon rainfall compared to Temerloh (0.045) and Kuantan (0.185). The subcomponents of average annual rainfall and household members being injured or dying as a result of the floods had the lowest vulnerability index, so they were considered to be the most invulnerable. According to what is documented in Table 8 , the food component had the highest vulnerability index value for Temerloh, and then Pekan and Kuantan. Meanwhile the water component delivered the lowest index value for all three districts. 
Table 6. Indexed subcomponents, main components, and total LVI for the Districts of Temerloh, Pekan and Kuantan.

\begin{tabular}{|c|c|c|c|c|c|c|c|}
\hline \multirow[t]{2}{*}{ Major Element } & \multirow[t]{2}{*}{ Subcomponent } & \multicolumn{3}{|c|}{ Subcomponent Index } & \multicolumn{3}{|c|}{ Major Component Index } \\
\hline & & $\mathbf{T}$ & $\mathbf{P}$ & $\mathbf{K}^{*}$ & $\mathbf{T}$ & $\mathbf{P}$ & $\mathbf{K}^{*}$ \\
\hline \multirow{8}{*}{$\begin{array}{l}\text { Social } \\
\text { demographic } \\
\text { profile }\end{array}$} & Ratio of dependence & 0.098 & 0.129 & 0.105 & 0.310 & 0.289 & 0.292 \\
\hline & $\begin{array}{l}\text { Percentage of female-headed } \\
\text { families }\end{array}$ & 0.198 & 0.155 & 0.065 & & & \\
\hline & $\begin{array}{l}\text { The average age of households } \\
\text { led by women }\end{array}$ & 0.577 & 0.619 & 0.539 & & & \\
\hline & $\begin{array}{l}\text { Families of heads of households } \\
\text { that did not attend school }\end{array}$ & 0.010 & 0.030 & 0.045 & & & \\
\hline & $\begin{array}{l}\text { The average number of } \\
\text { members in families }\end{array}$ & 0.357 & 0.357 & 0.286 & & & \\
\hline & $\begin{array}{l}\text { Percentage of families with } \\
\text { orphans }\end{array}$ & 0.064 & 0.040 & 0.090 & & & \\
\hline & $\begin{array}{l}\text { Percentage of households } \\
\text { where a member did not have } \\
\text { any formal or informal skills }\end{array}$ & 0.757 & 0.680 & 0.835 & & & \\
\hline & $\begin{array}{l}\text { Percentage of poor households } \\
\text { (income below RM490) }\end{array}$ & 0.415 & 0.300 & 0.371 & & & \\
\hline \multirow[t]{8}{*}{$\begin{array}{l}\text { Livelihood } \\
\text { strategy }\end{array}$} & $\begin{array}{l}\text { Households where a family } \\
\text { member works in another } \\
\text { community }\end{array}$ & 0.297 & 0.190 & 0.135 & 0.217 & 0.217 & 0.173 \\
\hline & $\begin{array}{l}\text { Families solely dependent on } \\
\text { agriculture as their primary } \\
\text { income source }\end{array}$ & 0.050 & 0.070 & 0.015 & & & \\
\hline & $\begin{array}{l}\text { Average agricultural livelihood } \\
\text { diversification }\end{array}$ & 0.874 & 0.785 & 0.956 & & & \\
\hline & $\begin{array}{l}\text { Agricultural work's } \\
\text { contribution to total income }\end{array}$ & 0.141 & 0.234 & 0.035 & & & \\
\hline & $\begin{array}{l}\text { Percentage of household } \\
\text { income with contributions from } \\
\text { farming activities }\end{array}$ & 0.198 & 0.245 & 0.075 & & & \\
\hline & $\begin{array}{l}\text { Percentage of households losing } \\
\text { a job during flood season }\end{array}$ & 0.045 & 0.025 & 0.050 & & & \\
\hline & $\begin{array}{l}\text { Percentage of households } \\
\text { finding natural resources } \\
\text { (during flood seasons) }\end{array}$ & 0.050 & 0.020 & 0.020 & & & \\
\hline & $\begin{array}{l}\text { Percentage of fish-catching } \\
\text { households (during flood } \\
\text { seasons) }\end{array}$ & 0.079 & 0.170 & 0.100 & & & \\
\hline \multirow[t]{6}{*}{ Health } & $\begin{array}{l}\text { Percentage of family members } \\
\text { with disease or illness }\end{array}$ & 0.035 & 0.060 & 0.060 & 0.215 & 0.228 & 0.197 \\
\hline & $\begin{array}{l}\text { Percentage of households that } \\
\text { do not keep medicines during } \\
\text { flood seasons }\end{array}$ & 0.208 & 0.370 & 0.540 & & & \\
\hline & $\begin{array}{l}\text { Percentage of households } \\
\text { without access to a healthcare } \\
\text { facility }\end{array}$ & 0.406 & 0.555 & 0.075 & & & \\
\hline & $\begin{array}{l}\text { Average time to get to the } \\
\text { nearest healthcare facility (at } \\
\text { least one qualified doctor) }\end{array}$ & 0.217 & 0.283 & 0.183 & & & \\
\hline & $\begin{array}{l}\text { For the last two weeks, } \\
\text { percentage of family members } \\
\text { that had to leave work or } \\
\text { schooling due to flood-caused } \\
\text { illness }\end{array}$ & 0.183 & 0.050 & 0.13 & & & \\
\hline & $\begin{array}{l}\text { Percentage of households where } \\
\text { family members had a disease } \\
\text { or illness due to flooding }\end{array}$ & 0.243 & 0.050 & 0.195 & & & \\
\hline
\end{tabular}


Table 7. Indexed subcomponents, main components, and total LVI for the Districts of Temerloh, Pekan and Kuantan.

\begin{tabular}{|c|c|c|c|c|c|c|c|}
\hline \multirow[t]{2}{*}{ Major Element } & \multirow[t]{2}{*}{ Subcomponent } & \multicolumn{3}{|c|}{ Subcomponent Index } & \multicolumn{3}{|c|}{ Major Component Index } \\
\hline & & $\mathbf{T}$ & $\mathbf{P}$ & $\mathbf{K}^{*}$ & $\mathrm{~T}$ & $\mathbf{P}$ & $\mathbf{K}^{*}$ \\
\hline \multirow[t]{7}{*}{ Social network } & $\begin{array}{l}\text { Average money borrowing/ } \\
\text { lending ratio }\end{array}$ & 0.933 & 1 & 0.300 & 0.473 & 0.511 & 0.438 \\
\hline & $\begin{array}{l}\text { Number of households } \\
\text { receiving government and NGO } \\
\text { assistance (during flood } \\
\text { seasons) }\end{array}$ & 0.96 & 0.890 & 0.705 & & & \\
\hline & $\begin{array}{l}\text { Percentage of households with } \\
\text { no access to } \\
\text { telecommunications services }\end{array}$ & 0.178 & 0.070 & 0.195 & & & \\
\hline & $\begin{array}{l}\text { Percentage of households not } \\
\text { volunteering during flooding }\end{array}$ & 0.653 & 0.660 & 0.860 & & & \\
\hline & $\begin{array}{l}\text { Percentage of households } \\
\text { without information about } \\
\text { flood evacuation centre }\end{array}$ & 0.054 & 0.105 & 0.190 & & & \\
\hline & $\begin{array}{l}\text { Percentage of households that } \\
\text { do not know how to get } \\
\text { information related to floods }\end{array}$ & 0.005 & 0.060 & 0.235 & & & \\
\hline & $\begin{array}{l}\text { Percentage of households not } \\
\text { sharing information about the } \\
\text { floods }\end{array}$ & 0.530 & 0.795 & 0.580 & & & \\
\hline \multirow[t]{5}{*}{ Food } & $\begin{array}{l}\text { Percentage of households that } \\
\text { did not keep reserves of food } \\
\text { during floods }\end{array}$ & 0.470 & 0.540 & 0.700 & 0.864 & 0.834 & 0.921 \\
\hline & Average crop diversity index & 0.899 & 0.823 & 0.976 & & & \\
\hline & $\begin{array}{l}\text { Average livestock diversity } \\
\text { index }\end{array}$ & 0.975 & 0.948 & 0.973 & & & \\
\hline & $\begin{array}{l}\text { Percentage of households not } \\
\text { storing crops }\end{array}$ & 1 & 0.945 & 0.985 & & & \\
\hline & $\begin{array}{l}\text { Percentage of households } \\
\text { without their own vegetable } \\
\text { garden }\end{array}$ & 0.975 & 0.915 & 0.970 & & & \\
\hline \multirow[t]{6}{*}{ Water } & $\begin{array}{l}\text { Percentage of households using } \\
\text { natural water resources }\end{array}$ & 0.020 & 0.020 & 0.020 & 0.110 & 0.082 & 0.069 \\
\hline & $\begin{array}{l}\text { Percentage of households } \\
\text { lacking a steady source of water }\end{array}$ & 0.015 & 0.030 & 0.005 & & & \\
\hline & $\begin{array}{l}\text { Percentage of households that } \\
\text { need to go far to get water }\end{array}$ & 0.015 & 0.015 & 0.035 & & & \\
\hline & $\begin{array}{l}\text { Households that have stored } \\
\text { water }\end{array}$ & 0.104 & 0.065 & 0.165 & & & \\
\hline & $\begin{array}{l}\text { Average distance to water } \\
\text { source }\end{array}$ & 0.500 & 0.333 & 0.186 & & & \\
\hline & $\begin{array}{l}\text { The inverse of the average } \\
\text { number of litres of water stored } \\
\text { per household (range: } 0-1 \text { ) }\end{array}$ & 0.006 & 0.030 & 0 & & & \\
\hline \multirow[t]{3}{*}{ House } & $\begin{array}{l}\text { Percentage of households } \\
\text { without a well-built house } \\
\text { (wood/semi-wood) foundation }\end{array}$ & 0.545 & 0.560 & 0.250 & 0.728 & 0.578 & 0.588 \\
\hline & $\begin{array}{l}\text { Percentage of houses not built } \\
\text { high enough to avoid floods }\end{array}$ & 0.827 & 0.730 & 0.965 & & & \\
\hline & $\begin{array}{l}\text { Percent of households affected } \\
\text { by floods }\end{array}$ & 0.812 & 0.445 & 0.550 & & & \\
\hline Land & $\begin{array}{l}\text { Percentage of households not } \\
\text { owning land on which they } \\
\text { reside (landless) }\end{array}$ & 0.371 & 0.215 & 0.310 & 0.600 & 0.455 & 0.621 \\
\hline
\end{tabular}


Table 8. Indexed subcomponents, main components, and total LVI for the Districts of Temerloh, Pekan and Kuantan.

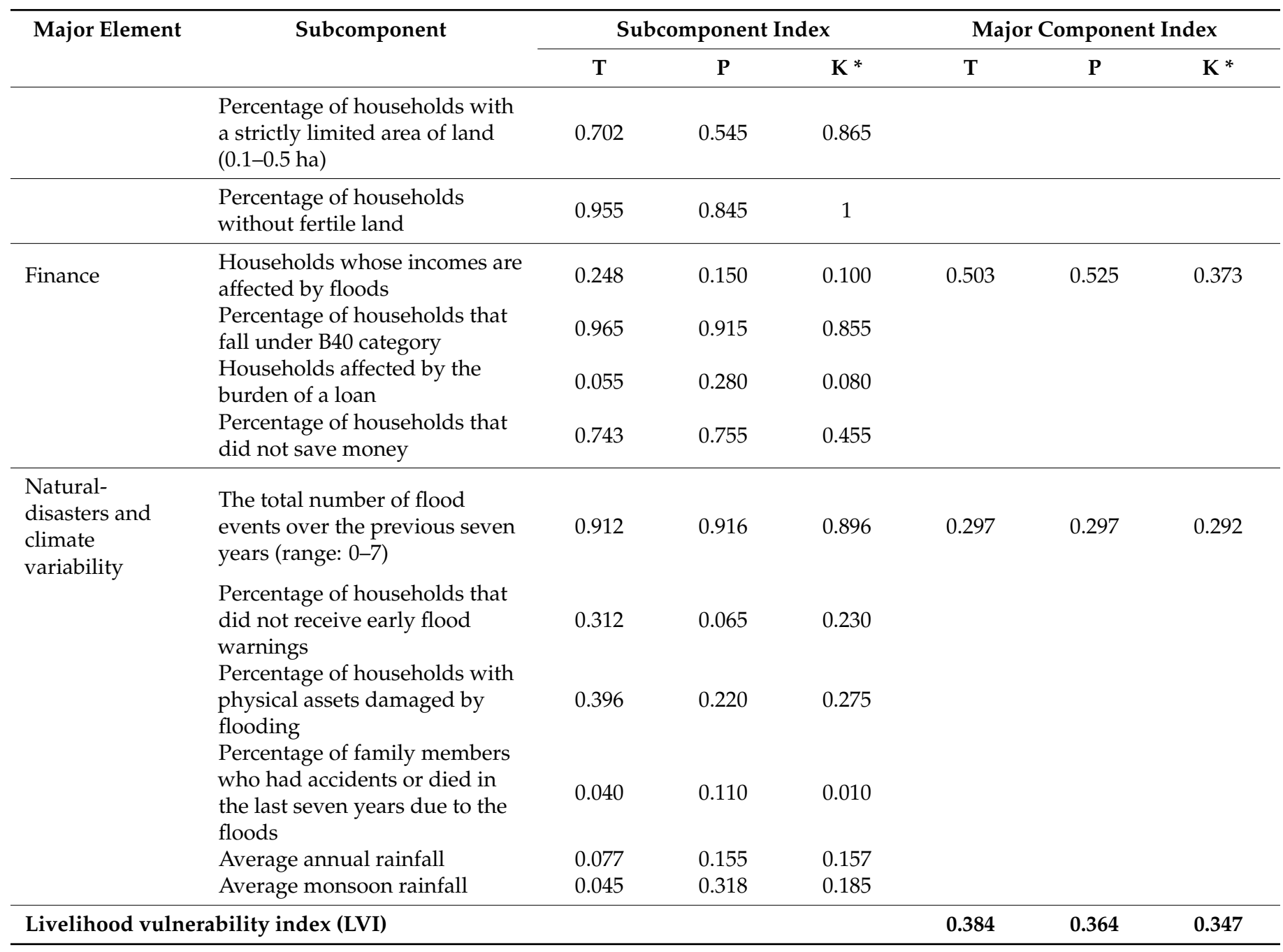

Note: ${ }^{\mathrm{T}}=$ Temerloh, $\mathrm{P}=$ Pekan, and $\mathrm{K}=$ Kuantan.

When referring to Figure 2 and Table 5, we find out that each component could be categorised into four ranges of the vulnerability scale. Food is the only major component classified as most vulnerable (MV). Most of the components were categorised as vulnerable (V); house, land and finance, including social network in Pekan. Meanwhile, another three major components were classified as invulnerable (IV), specifically social demographic profile, social network, and natural-disaster and climate variability. There were two other significant part of major components that categorised as invulnerable, and these were land in Pekan and finance in Kuantan. Consequently, the three components that emerge as part of the most invulnerable (MI) scale are livelihood strategy, health, and water.

According to the Table 9 of LVI-IPCC contributing factors, shows that Temerloh and Pekan (0.297) had the same vulnerability to the consequences of climate change more than Kuantan (0.292). Temerloh (0.460) was more vulnerable to climate change than both Pekan (0.417) and Kuantan (0.427), and this accounts for the current state of food, natural resources, household, property and people's finances. Meanwhile, based on social network, social demographic profile, and livelihood strategy, Pekan (0.332) revealed a more adaptive capacity than Temerloh (0.327) and Kuantan (0.295). The overall LVI-IPCC scores for Temerloh $(-0.013)$ and Pekan $(-0.014)$ were lower than Kuantan $(-0.001)$. It indicated that Kuantan is more vulnerable to climate change compared to the other two districts due to almost similar exposure and high sensitivity but with low adaptive capacity towards the floods. 


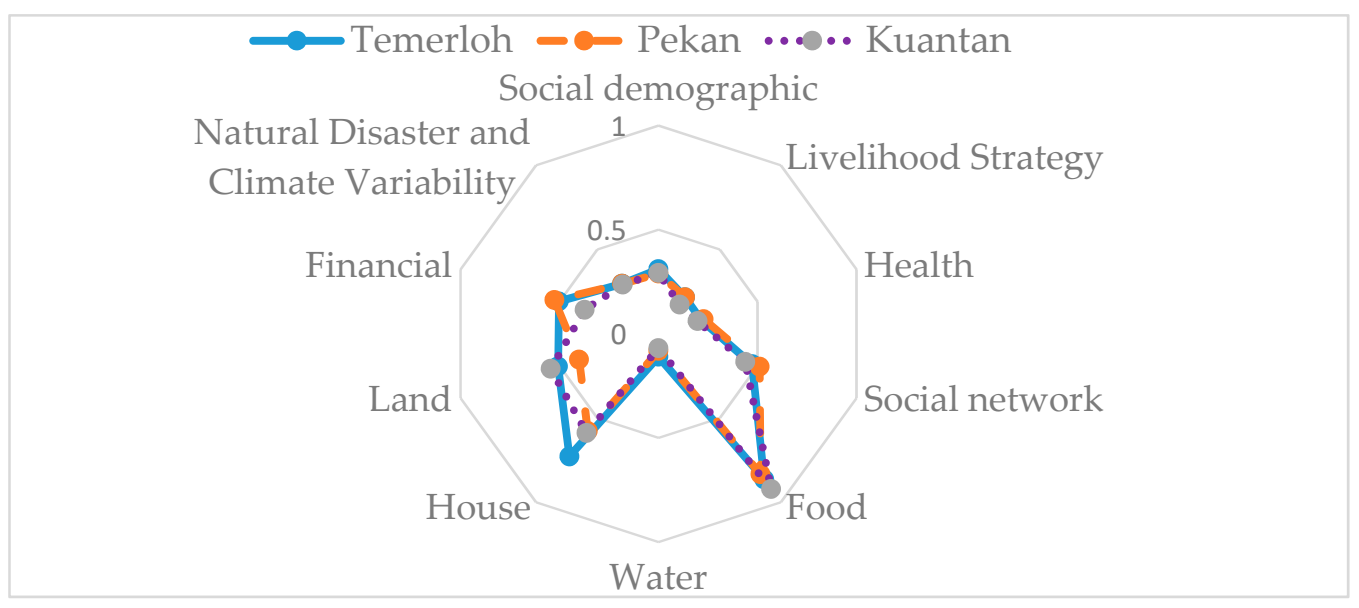

Figure 2. 'Spider web' depiction of the Temerloh, Pekan, and Kuantan districts with the 10 main elements of LVI.

Table 9. LVI-IPCC contributing factors calculation for Temerloh, Pekan, and Kuantan districts.

\begin{tabular}{cccc}
\hline Contributing Factors & Temerloh & Pekan & Kuantan \\
\hline Adaptive Strategy & 0.327 & 0.332 & 0.295 \\
Sensitivity & 0.444 & 0.410 & 0.411 \\
Exposure & 0.297 & 0.297 & 0.292 \\
Overall LVI - IPCC & $\mathbf{- 0 . 0 1 3}$ & $\mathbf{- 0 . 0 1 4}$ & $\mathbf{- 0 . 0 0 1}$ \\
\hline
\end{tabular}

Source: Author analysis, 2019.

\section{Discussion}

Floods increase the vulnerabilities of affected communities in various ways. The dependency ratio for each household was based on the level of education that the head of each household had: the higher level of education, then the lower the household's dependency level was [24]. Thus, most of the heads of households in Temerloh, Pekan, and Kuantan had received a formal education only to the end of primary school. Among the impacted population, there is a substantial number of homes run by women. However, whether or not households headed by female adults are more prone to the consequences of climate change cannot be ascertained [23]. Compared to uneducated households which have only little or no ability to earn money and move to other regions, households with family members who have education qualifications have a better chance of finding employment [33]. One study has shown that a household's lack of potential life-saving skills will increase its vulnerability to climate change and associated disasters [34]. Poor households with incomes below RM490 per month will be more vulnerable to floods. The evidence from [35] is that natural disasters will affect incomes and especially those of lower-income groups.

The subcomponent of livelihood strategies suggests that the highest diversity of agricultural activities recorded in Temerloh and Pekan districts were involved five agricultural activities covering the planting of crops and looking after livestock. Meanwhile, the highest diversity of agricultural activities recorded in Kuantan is about four agricultural activities per household. This means that Temerloh and Pekan are less vulnerable than Kuantan according to the livelihood strategies that have been documented by [23]. The subcomponent of natural resources being used to tide people over during floods shows the lowest vulnerability index value under the component of livelihood strategy. Not many people have the skills to find and use natural resources to protect themselves during floods.

Every household should have the financial capacity to withstand floods. The finances of each family generally consist of two important items: periodic incomes and investments made by the households [36]. More than 90\% of respondents were under the B40 category, with 30 to $42 \%$ of respondents having a monthly income below RM940 (considered poor and hardcore poor, respectively). Therefore, besides depending on the household's main 
wage earner and saving money when floods occur, flood insurance is considered to be a nonphysical adaptation measure. However, this strategy is not familiar to most people in Malaysia. While people in Malaysia are greatly affected by floods every year, flood insurance is not part of a robust integrated flood risk management scheme [37]. A proper insurance plan is highly recommended to reduce the vulnerability of local communities in flood-prone areas. For the component social network, in Temerloh and Pekan, most respondents prefer to borrow money rather than lend it, compared to those in Kuantan. Nevertheless, most respondents in Kuantan can afford a more stable lifestyle and have regular monthly salaries compared to the other two districts. This advantage is due to better job opportunities in government and the private sector. Households that tend to borrow money will be more vulnerable compared to those lending moneys.

The majority of respondents in Temerloh and Pekan received assistance from government and NGOs when floods struck. The rising number of households requiring assistance from the government and NGOs means that the majority of families are vulnerable. Through this subcomponent of ratio of borrowing/lending money, each household receiving assistance represents its level of dependence on family and friends [23]. A small number of respondents did not have access to telecommunications services, and this situation is typical for older citizens. Almost all respondents receive their information about floods through social media, television, and radio. However, they seldom share it with their neighbours and friends. The small percentage of households' members participating as volunteers during floods increases overall vulnerability. More people offering to be work as volunteers leads to better flood resilience [38] and empowers the community to do better.

Households that are suffering due to a family member having a chronic illness or disease ranges from only 3.5 to $6 \%$. However, in the Temerloh and Pekan districts, the number of households lacking access to the closest healthcare facility is comparatively high. Although the average distance to the nearest healthcare facility is between 11 to $17 \mathrm{~min}$, this situation might depend on the how respondents defined 'chronic illness' because it is very subjective [24]. This scenario is also partially affected by households' low income, lack awareness of good health [39], and lack of proper transportation. Conversely, most respondents in Kuantan have easy access to the nearest healthcare facility compared to the other two districts because people in Kuantan generally have their own cars and motorcycles, compared to respondents in rural areas. Easy access to the nearest healthcare facility is perhaps one reason why respondents in Kuantan did not store medications during floods, because they can acquire them easily enough.

In this study, the high vulnerability level detected for the food component reflects the fact that a small number of households working in agriculture have only small food crops and livestock. Meanwhile a high percentage of families do not get their food resources from home vegetable gardens. Most households that plant crops do not in fact store them for food security when a flood strikes. In terms of food storage during times of flood, respondents in Temerloh and Pekan were more prepared compared to those in Kuantan. Due to limited stock being available during floods, most households will prepare stockpiles of dry, packaged, and canned foods in preparation for such events. They have had much experience of this situation and are potentially exposed to floods and their consequences virtually every year. Food supplies become highly vulnerable because most households do not plant crops as "backup" food sources. However, regular floods whether high or low in magnitude still severely damage crops and cause food scarcity conditions to emerge [37]. In fact, most flood-affected households suffer from food scarcity, which is not helped by not having any such supplies or savings to tide them over [40].

Most households in all three districts did not experience disruption to their water supply. Only $5 \%$ and less of households experience this problem. They do have another option to get water, which is from wells or the river. The average time taken to get to a water supply source can be between 12 to $30 \mathrm{~min}$. Respondents in Temerloh and Pekan need to travel farther to reach another water source compared to respondents in Kuantan 
if a water disruption occurs. There are still a few households having to ensure they have enough water stored away for their daily usage. Although the supply of clean water is not a problem in Temerloh, Pekan, and Kuantan, they do all suffer from the threat of postflood-borne diseases or illnesses which spread through contaminated drinking water [41]. For this reason, it is always extremely important to keep the supply of water clean for human consumption.

The majority of respondents' abodes were built as single-storey houses. Homes that were erected close to the ground are continually exposed to and damaged by floods. Most households did not elevate their residences above the ground because it is too expensive to do, so they are at the mercy of flood events. Respondents' houses are mostly built according to traditional designs and are of wood construction, especially in Temerloh and Pekan districts. Consequently, to ensure the safety of all people in the community and resist floods as much as possible, homes should be built with a strong concrete structure and not wood or semiwood/semiconcrete materials [42]. Most of the homes in Kuantan have been built utilising a concrete structure reinforced with bricks and cement.

Most respondents did not own enough or any fertile land on which to do agriculture. Also, when respondents did own some land, they did not use it to plant anything for their household consumption. More than $50 \%$ of respondents have land which is modest in size, ranging between $0.1-0.5$ ha. These households do not prefer to plant crops around the residential home, since space is at a premium. It is one indicator of the high vulnerability of the land component. A small percentage of households do not own the land on which they reside so they are in effect landless; most other respondents owned their land either through purchase or inheritance. Households without land to own and use as they see fit are therefore more vulnerable to a flooding crisis $[25,26]$.

Referring to the finance component, more than $80 \%$ of respondents in the three districts were under B40, which is the category for households earning RM 3860 or less per month [43]. Many respondents did not save enough of their incomes and the majority of households had incomes that essentially were the same before and after flood events. A household that is in the B40 category generally is classified as self-employed and/or working in agriculture. Households with the burden of having to pay off a loan normally borrow money from their family and friends for a car or a house. Most respondents experience floods every year in these three districts and have go through it so for a long time. Although the losses and damage are higher in Temerloh compared to the other two districts, the average annual precipitation and monsoon rainfalls reported in Temerloh are much lower than in Pekan and Kuantan. In addition, only a small number of households did not received an early warning about an imminent flood event. However, it is necessary to devise and implement the best adaptation strategy to reduce the vulnerability index for each significant component involved. Adaptation measures that can be useful to respondents may include physical and nonphysical adaptation techniques. Local communities in Pahang have already developed several such measures to diminish flood-caused damage. If the risk of floodwater incursion into "living spaces" is evident, then using some form of measure to curtail the outcomes of that incursion is sensible [39]. The steps taken by people in the study areas are strongly dictated by economic considerations and realities [40].

Generally, Temerloh, Pekan, and Kuantan districts are exposed to high socioeconomic vulnerability in certain ways due to their communities' poor ability to adapt to monsoon floods event. This study has identified these three areas as "hot spots" that need to develop new strategies and find practical solutions. It means involving all relevant policymakers, government agencies and the local communities working together to implement appropriate risk management strategies [44].

\section{Recommendations and Policy Implications}

In Malaysia, the government has issued a general nation-wide policy that applies to all types of disasters, including floods. It is therefore evident that disaster management does not specifically focus on a certain type of disaster or the specific context in which 
it occurs [45]. Previous studies have criticised the flood relief policies that have been devised by Malaysian officials over the decades. Unfortunately, the Malaysian tiers of government put food relief plans into action only after a disaster has occurred and do not actually put measures in place beforehand [46]. Therefore, the main four stages are requiring for flood management in Malaysia which is prevention/mitigation, preparedness, response, and recovery [47]. As a minimum requirement, disaster prevention/mitigation and preparedness are certainly the best path forward since the pressure of the stages will be minimized if these two stages are managed successfully as state by [48].

Flood disasters have caused massive losses of life and damage to personal and public property. The loss and destruction of all kinds of property require urgent remedial action so that people's lives can return to normal as quickly as possible when a flood has occurred. The process of rebuilding and rehabilitating public infrastructure and facilities such as roads, schools, hospitals, irrigation, and drainage systems requires government agencies and departments, such as the State Government, Federal Department of Town and Country Planning (JPBD), Malaysian Public Works Department (JKR), Education Department, Health Department and Department of Irrigation and Drainage (DID), etc., to work together and know what their particular responsibilities are. Money needs to be set aside in state and federal government revenues for reconstruction of wrecked and damaged infrastructure and people's homes.

Given the urgent needs of victims, a sophisticated postdisaster policy must be put in place, one that can mitigate or predict damage, guarantee temporary disaster relief and recovery, and improve the welfare of victims' lives [49]. Victims of floods need some form of compensation to help them recover and rebuild their lives when their property and goods are damaged or destroyed. The process of distributing assistance and compensation through the state and federal governments should be hastened and improved. While victims absorb the brunt of the damage, they expect disaster relief to be provided by both public and private sector sources [45]. It is essential that there is collaboration between corporates, NGOs, CBOs, political parties, and individuals to help flood victims who cannot rebuild their lives by themselves.

Flood victims typically are threatened by the loss of work, income, and especially those who depend almost solely agriculture/farming activities. Compensation for loss of income should be guaranteed so that the victims can start their lives almost immediately and not have to go through a bureaucratic or "red tape" maze of rules, exclusions, etc. It is important that no one is omitted from the postdisaster assistance process. On the other hand, the actions of donor or humanitarian agencies that "dump" food and clothing on affected communities, need to be closely monitored and coordinated properly to avoid wasted resources. Although various policies have been implemented for all kinds of disasters, some problems still remain during the postdisaster phase, especially in terms of policy enforcement and process of recovery for victims [50]. Ultimately, ineffective disaster management policy and implementation diminish the quality of life of flood victims [51].

\section{Conclusions}

The LVI methods were employed in this research to assess the socioeconomic effects of floods in the districts of Temerloh, Pekan, and Kuantan which are located in Pahang State, Malaysia. LVI and IPCC helped to establish the basic vulnerability of communities in these areas towards floods and climate change. In terms of food requirements, all three areas are in particular most vulnerable to great risk during floods. On the other hand, the water component shows the lowest vulnerability index. Overall, the three areas of study show that there is extremely high sensitivity in term of vulnerable on the food, health, land, and financial aspects. The distress of community to adapt with the effects of climate change will be stimulated. It is essential to reduce vulnerability of livelihood, which is measured by the community's resilience and ability to overcome risk and disaster through its ability to adapt to circumstances. Besides that, by understanding livelihood vulnerabilities of communities exposed to floods risk will assist the local authorities proper plan 
towards sustainable socioeconomic development in future. Climate change is currently becoming worse worldwide, and in Malaysia it is leading to more floods and therefore more people at risk of losing their livelihoods, incomes, and resources. Integrating better flood mitigation strategies could prevent dangerous levels of socioeconomic vulnerability around the river basin areas and enable local communities to survive and prosper. Future studies should build on the findings reported here by investigating vulnerability issues elsewhere in Malaysia and make more in-depth comparisons. It is currently difficult to determine the precise subcomponents that indicate the real value of livelihood vulnerabilities, since all communities will have their own economic, cultural, social, and environmental circumstances to navigate.

Author Contributions: Conceptualization, A.N.A. and M.I.N.D.; Data curation, M.I.N.D.; Formal analysis, A.N.A.; Funding acquisition, M.I.N.D.; Investigation, M.I.N.D., M.M.A., and M.Y.; Methodology, M.I.N.D.; Project administration, M.I.N.D.; Resources, A.N.A.; Software, M.I.N.D.; Supervision, C.S.; Validation, M.I.N.D., C.S., and M.M.A.; Visualization, A.N.A.; Writing-original draft, A.N.A. and M.I.N.D.; Writing-review \& editing, M.I.N.D. and M.M.A. All authors have read and agreed to the published version of the manuscript.

Funding: This research was funded by Ministry of Higher Education of Malaysia, grant number FRGS/1/2018/SS08/UKM/03/1.

Data Availability Statement: Not applicable.

Acknowledgments: The authors acknowledged the administration and technical support by Nurul Atikah Zulkepli for the kind of searching material of this study.

Conflicts of Interest: The authors declare no conflict of interest. The funders had no role in the design of the study; in the collection, analyses, or interpretation of data; in the writing of the manuscript; or in the decision to publish the results.

\begin{tabular}{ll}
\multicolumn{2}{l}{ Abbreviations } \\
A & Water \\
AdaCap & Adaptive Capacity \\
Exp & Exposure \\
Fi & Financial \\
F & Food \\
H & Health \\
Ho & House \\
L & Land \\
Sen & Sensitivity \\
IPCC & Intergovernmental Penal on Climate Change \\
LS & Livelihood Strategy \\
LVI & Livelihood Vulnerability Index \\
NDCV & Natural-Disaster and Climate Variability \\
PLI & Poverty-Line Income \\
SDP & Social Demographic Profile \\
SLA & Sustainable Livelihood Approach \\
SN & Social Network
\end{tabular}

\section{References}

1. Tang, K.H.D. Climate change in Malaysia: Trends, contributors, impacts, mitigation and adaptations. Sci. Total. Environ. 2019, 650, 1858-1871. [CrossRef]

2. Yeganeh, N.; Sabri, S. Flood Vulnerability Assessment in Iskandar Malaysia Using Multi-criteria Evaluation and Fuzzy Logic. Res. J. Appl. Sci. Eng. Technol. 2014, 8, 1794-1806. [CrossRef]

3. Apurv, T.; Mehrotra, R.; Sharma, A.; Goyal, M.K.; Dutta, S. Impact of climate change on floods in the Brahmaputra basin using CMIP5 decadal predictions. J. Hydrol. 2015, 527, 281-291. [CrossRef]

4. Muhammad, N.S.; Abdullah, J.; Julien, P.Y. Characteristics of Rainfall in Peninsular Malaysia. J. Phys. Conf. Ser. 2020, 1529. [CrossRef] 
5. Chang, C.K.; Ghani, A.A.; Zakaria, N.A.; Puay, H.T. Sediment Transport in Sungai Pahang: Case Study of a Large Scale River Basin. J. Teknol. 2015, 72, 2180-3722.

6. Khan, M.M.; Shaari, N.A.; Bahar, A.M.; Baten, M.A.; Nazaruddin, D.B. Flood Impact Assessment in Kota Bharu, Malaysia: A Statistical Analysis. World Appl. Sci. J. 2014, 32, 626-634. [CrossRef]

7. Chambers, R.; Conway, G.R. Sustainable Rural Livelihoods: Practical Concepts for the 21st Century; IDS Discussion Paper, 296; Institute of Development Studies: Brighton, UK, 1992.

8. DFID. Sustainable Livelihoods Guidance Sheets; DFID: London, UK, 1999.

9. IPCC. Climate Change 2007: Impacts, adaptation and vulnerability. In Contribution Group II to the Fourth Assessment Report of the Intergovernmental Panel on Climate Change; Parry, M.L., Canziani, O.F., Palutikof, J.P., van der Linden, P.J., Hanson, C.E., Eds.; Cambridge University Press: Cambridge, UK, 2007.

10. Turner, B.L.; Kasperson, R.E.; Matson, P.A.; McCarthy, J.J.; Corell, R.W.; Christensen, L.; Eckley, N.; Kasperson, J.X.; Luers, A.; Martello, M.L.; et al. A framework for vulnerability analysis in sustainability science. Proc. Natl. Acad. Sci. USA 2003, 100, 8074-8079. [CrossRef]

11. Marin, G.; Modica, M. Socio-economic exposure to natural disasters. Environ. Impact Assess. Rev. 2017, 64, 57-66. [CrossRef]

12. Eriksen, S.H.; Kelly, P.M. Developing Credible Vulnerability Indicators for Climate Adaptation Policy Assessment. Mitig. Adapt. Strat. Glob. Chang. 2007, 12, 495-524. [CrossRef]

13. Pinto, M.M.S.C.; Marinho-Reis, P.; Almeida, A.; Pinto, E.; Neves, O.; Inácio, M.; Gerardo, B.; Freitas, S.; Simões, M.R.; Dinis, P.A.; et al. Links between Cognitive Status and Trace Element Levels in Hair for an Environmentally Exposed Population: A Case Study in the Surroundings of the Estarreja Industrial Area. Int. J. Environ. Res. Public Heal. 2019, 16, 4560. [CrossRef] [PubMed]

14. Gbetibouo, G.A.; Ringler, C. Mapping South African farming sector vulnerability to climate change and variability. Nat. Resour. Forum 2010, 34, 175-187. [CrossRef]

15. Preston, B.L.; Yuen, E.; Westaway, R.M. Putting vulnerability to climate change on the map: A review of approaches, benefits, and risks. Sustain. Sci. 2011, 6, 177-202. [CrossRef]

16. Adger, W.N. Vulnerability. Glob. Environ. Chang. 2006, 16, 268-281. [CrossRef]

17. Cabral Pinto, M.M.S.; Ferreira da Silva, E.A. Heavy Metals of Santiago Island (Cape Verde) alluvial deposits: Baseline value maps and human health risk assessment. Int. J. Environ. Res. Public Health 2019, 16, 2. [CrossRef]

18. Cabral Pinto, M.M.S.; Marinho-Reis, A.P.; Almeida, A.; Freitas, S.; Simões, M.R.; Diniz, M.L.; Pinto, E.; Ramos, P.; Ferreira da Silva, E.; Moreira, P.I. Fingernail trace element content in environmentally exposed individuals and its influence on their cognitive status in ageing. Expo. Health 2019, 11, 181-194. [CrossRef]

19. JICA. The Preparatory Survey for Integrated River Basin Management Incorporating Integrated Flood Management with Adaptation of Climate Change; JICA: Tokyo, Japan, 2011.

20. Zad, S.N.M.; Diyana, Z.; Muharam, F.M. Satellite Rainfall (TRMM 3B42-V7) Performance Assessment and Adjustment over Pahang River Basin, Malaysia. Remote. Sens. 2018, 10, 388. [CrossRef]

21. Ab Ghani, A.; Chang, C.K.; Leow, C.S.; Zakaria, N.A. Sungai Pahang digital flood mapping: 2007 flood. Int. J. River Basin Manag. 2012, 10, 139-148. [CrossRef]

22. Toriman, M.E.; Mokhtar, M. Irrigation: Types, Sources and Problems in Malaysia. In Irrigation Systems and Practices in Challenging Environments; IntechOpen: London, UK, 2012.

23. Hahn, M.B.; Riederer, A.M.; Foster, S.O. The Livelihood Vulnerability Index: A pragmatic approach to assessing risks from climate variability and change-A case study in Mozambique. Glob. Environ. Chang. 2009, 19, 74-88. [CrossRef]

24. Tewari, H.R.; Bhowmick, P.K. Livelihood vulnerability index analysis: An approach to study vulnerability in the context of Bihar. Jàmbá J. Disaster Risk Stud. 2014, 6, 13. [CrossRef]

25. Majid, N.A.; Nazi, N.M.; Diana, M.I.N.; Taha, M.R. GIS-Based Livelihood Vulnerability Index Mapping of the Socioeconomy of the Pekan Community. Sustainability 2019, 11, 6935. [CrossRef]

26. Diana, M.I.N.; Chamburi, S.; Raihan, T.M.; Ashikin, A.N. Assessing local vulnerability to climate change by using Livelihood Vulnerability Index: Case study in Pahang region, Malaysia. IOP Conf. Ser. Mater. Sci. Eng. 2019, 506, 012059. [CrossRef]

27. Panthi, J.; Aryal, S.; Dahal, P.; Bhandari, P.; Krakauer, N.Y.; Pandey, V.P. Livelihood vulnerability approach to assessing climate change impacts on mixed agro-livestock smallholders around the Gandaki River Basin in Nepal. Reg. Environ. Chang. 2016, 16, 1121-1132. [CrossRef]

28. Etwire, P.M.; Al-Hassan, R.M.; Kuwornu, J.K.M.; Osei-Owusu, Y. Application of Livelihood Vulnerability Index in Assessing Vulnerability to Climate Change and Variability in Northern Ghana. J. Environ. Earth Sci. 2013, 3, 157-170.

29. Adu, D.T.; Kuwornu, J.K.; Anim-Somuah, H.; Sasaki, N. Application of livelihood vulnerability index in assessing smallholder maize farming households' vulnerability to climate change in Brong-Ahafo region of Ghana. Kasetsart J. Soc. Sci. 2018, 39, 22-32. [CrossRef]

30. Alam, G.M.M.; Alam, K.; Mushtaq, S.; Clarke, M.L. Vulnerability to climatic change in riparian char and river-bank households in Bangladesh: Implication for policy, livelihoods and social development. Ecol. Indic. 2017, 72, 23-32. [CrossRef]

31. Tjoe, Y. Measuring the livelihood vulnerability index of a dry region in Indonesia. World J. Sci. Technol. Sustain. Dev. 2016, 13, 250-274. [CrossRef]

32. Koirala, S. Livelihood Vulnerability Assessment to the Impacts of Socio-Environmental Stressors in Raksirang VDC of Makwanpur District Nepal. Master's Thesis, Norwegian University of Life Sciences, As, Norway, 2015. [CrossRef] 
33. Cutter, S.L.; Boruff, B.J.; Shirley, W.L. Social Vulnerability to Environmental Hazards*. Soc. Sci. Q. 2003, 84, 242-261. [CrossRef]

34. Alim, A. Changes in villagers' knowledge, perceptions, and attitudes concerning gender roles and relations in Bangladesh. Dev. Pr. 2009, 19, 300-310. [CrossRef]

35. Ibrahim, A.Z.; Siwar, C. Kelestarian Penghidupan Petani Luar Bandar; Universiti Utara Malaysia: Sintok, Malaysa, 2017.

36. Braun, B.; Aßheuer, T. Floods in megacity environments: Vulnerability and coping strategies of slum dwellers in Dhaka/Bangladesh. Nat. Hazards 2011, 58, 771-787. [CrossRef]

37. Aliagha, U.G.; Jin, T.E.; Choong, W.W.; Jaafar, M.N.; Ali, H.M. Factors affecting flood insurance purchase in residential properties in Johor, Malaysia. Nat. Hazards Earth Syst. Sci. 2014, 14, 3297-3310. [CrossRef]

38. O'Brien, L.; Ambrose-oji, B.; Morris, J.; Edwards, D.; Williams, R. Volunteers' Contribution to Flood Resilience; Environment Agency: Bristol, UK, 2014; pp. 1-8.

39. Few, R. Flooding, vulnerability and coping strategies: Local responses to a global threat. Prog. Dev. Stud. 2003, 3, 43-58. [CrossRef]

40. Brouwer, R.; Akter, S.; Brander, L.; Haque, E. Socioeconomic Vulnerability and Adaptation to Environmental Risk: A Case Study of Climate Change and Flooding in Bangladesh. Risk Anal. 2007, 27, 313-326. [CrossRef]

41. Paul, S.K.; Routray, J.K. Flood proneness and coping strategies: The experiences of two villages in Bangladesh. Disasters 2010, 34, 489-508. [CrossRef]

42. Marfai, M.A.; Sekaranom, A.B.; Ward, P.J. Community responses and adaptation strategies toward flood hazard in Jakarta, Indonesia. Nat. Hazards 2015, 75, 1127-1144. [CrossRef]

43. EPU. Perangkaan Pendapatan dan Kemiskinan isi Rumah Sepintas Lalu; EPU: Putrajaya, Malaysia, 2012.

44. Abdullah, P.; Salleh, S.; Elfithri, R.; Mokhtar, M.; Toriman, M.E.; Embi, A.F.; Maulud, K.N.A.; Abdullah, M.; Heng, L.Y.; Halimshah, S.; et al. Stakeholders' Response and Perspectives on Flood Disaster of Pahang River Basin. Malays. J. Geosci. 2017, 1, 43-49. [CrossRef]

45. Shafiai, S. Flood Disaster Management in Malaysia: A Review of Issues of Flood Disaster Relief during and Post-Disaster. In Proceedings of the ISSC 2016 International Conference on Soft Science, Kedah, Malaysia, 11-13 April 2016; pp. 163-170.

46. Aldrich, D.P.; Oum, S.; Sawada, Y. Resilience and Recovery in Asian Disasters; Springer: Berlin/Heidelberg, Germany, 2015; pp. 239-265. [CrossRef]

47. Yusoff, I.M.; Ramli, A.; Alkasirah, N.A.M.; Nasir, N.M. Exploring the managing of flood disaster: A Malaysian perspective. Malays. J. Soc. Space 2018, 14, 24-36. [CrossRef]

48. Baharuddin, K.A.; Wahab, S.F.A.; Rahman, N.H.N.A.; Mohamad, N.A.N.; Kamauzaman, T.H.T.; Yazid, M.N.A.; Majid, M.R.A. The record-setting flood of 2014 in kelantan: Challenges and recommendations from an emergen-cy medicine perspective and why the medical campus stood dry. Malays. J. Med Sci. 2015, 22, 1-7.

49. Badri, S.A.; Asgary, A.; Eftekhari, A.; Levy, J. Post-disaster resettlement, development and change: A case study of the 1990 Manjil earthquake in Iran. Disasters 2006, 30, 451-468. [CrossRef]

50. Hamin, Z.; Othman, M.B.; Elias, Z. Floating on a Legislative Framework in Flood Management in Malaysia: Lessons from the United Kingdom. Procedia Soc. Behav. Sci. 2013, 101, 277-283. [CrossRef]

51. Roosli, R.; O'Brien, G. Social learning in managing disasters in Malaysia. Disaster Prev. Manag. Int. J. 2011, 20, 386-397. [CrossRef] 